TECHNICAL SCIENCES AND TECHNOLOGIES

УДК 628.16

DOI: $10.25140 / 2411-5363-2019-4(18)-215-222$

\title{
Олександр Квартенко
}

\section{ЗАСТОСУВАННЯ КОМБІНОВАНИХ МЕТОДІВ У ТЕХНОЛОГІЯХ ОЧИЩЕННЯ БАГАТОКОМПОНЕНТНИХ ПІДЕМНИХ ВОД}

\begin{abstract}
Актуальність теми дослідження. Існуючі технології є екстенсивними та не передбачають комплексного очищення підземних вод від забруднень природного та антропогенного походження.

Постановка проблеми. Наукове обтрунтування, дослідження та впровадження технологічного рішення, яке передбачає комплексне очищення в результаті комбінування відомих та удосконалених методів.

Аналіз останніх досліджень та публікацій. Найбільш поширеною є технологія очищення за методом спроще-

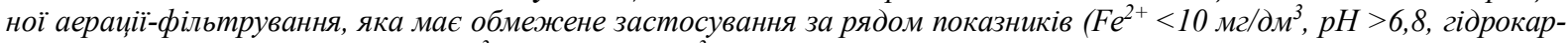

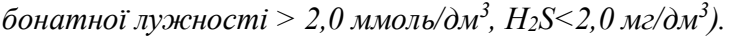

Виділення недосліджених частин загальної проблеми. Розробка та впровадження технології, в основі якої закладено приниип синергізму комплексного використання комбінованих методів.

Мета статті. Розвиток науково-технічних засад у галузі комплексного очищення природних підземних вод із використанням комбінованих методів.

Виклад основного матеріалу. Встановлено, що при відповідній комбінаторииі відомих та удосконалених методів із використанням синергетичного ефекту швидкість проходження процесів очищення багатокомпонентних систем є не на багато нижчою, ніж для однокомпонентних $\left(\mathrm{Fe}^{2+}\right)$. Розроблено теоретичні засади комплексного очищення підземних вод від сполук феруму, амонійного нітрогену, фенолів, хрому(IV) з використанням методів гідродинамічної кавітачії - підлуження - коагулячиї - біохімічного очищення - фільтрування.

Висновки відповідно до статті. Для очищення слабокислих (рH до 6,5) підземних вод з низьким лужним резервом (до

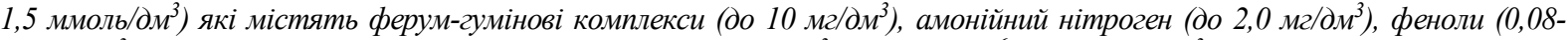
$\left.0,5 \mathrm{мz} / \partial \mathrm{m}^{3}\right)$, легко-окиснювальні органічні сполуки (до 8 мг $\left.\mathrm{O}_{2} / \partial \mathrm{m}^{3}\right)$, катіони $\mathrm{Cr}^{6+}\left(\partial о 0,5 \mathrm{мz} / \partial \mathrm{m}^{3}\right)$ розроблено та впроваджено технологію, в основі якої закладено принцип синергізму використання відомих та удосконалених комбінованих методів.

Ключові слова: комплексне очищення; матриксні структури; гідродинамічна кавітація; феноли; амонійний нітроген.

Рис.: 3. Бібл.: 16
\end{abstract}

Актуальність теми дослідження. Наявні технології очищення підземних вод не передбачають комплексного очищення від забруднень як природного, так і антропогенного походження та грунтуються здебільшого на принципі поетапного вилучення лише окремих забруднюючих інгредієнтів. Такий підхід є екстенсивним та призводить до збільшення кількості та об’єму технологічних споруд.

Постановка проблеми. Проведені моніторингові дослідження параметрів якості підземних вод [1] вказали на наявність у них забруднень як природного (завислі речовини, кольоровість, агресивний карбон(IV) оксид, легкоокиснювані органічні речовини, комплексні органічні речовини, гумінові кислоти, сполуки $\mathrm{Fe}^{2+}, \mathrm{Mn}^{2+}$ ), так і антропогенного характеру (іони $\mathrm{Cr}^{6+}, \mathrm{Cu}^{2+}, \mathrm{NH}_{4}^{+}, \mathrm{NO}_{2}^{-}, \mathrm{NO}_{3}^{-}$, феноли, сполуки фосфору, поверхнево активні речовини). Більшість існуючих в Україні станцій очищення підземних вод було введено в експлуатацію в середині 70-х років ХX століття за технологією фільтрування зі спрощеною аерацією, яка не передбачала комплексне видалення наведених вище забруднень. Крім того, існуючі технології $є$ екстенсивними, енергоємними, зі значними капітальними та експлуатаційними витратами. Тому наукове обгрунтування, дослідження та впровадження технологічного рішення, яке передбачає комплексне очищення підземних вод у результаті комбінування як відомих так і удосконалених фізичних, біологічних та фізико-хімічних методів, є актуальним.

Аналіз останніх досліджень та публікацій. Одними з найбільш поширених забруднювачів природних вод $\epsilon$ сполуки феруму, для очищення від якого використовують фізикохімічні методи глибокої та спрощеної аерації з наступним фільтруванням [2; 3]. Метод спрощеної аерації - фільтрування має обмеження за використанням щодо вмісту йонів $\mathrm{Fe}^{2+}$ до $10 \mathrm{Mг} /$ дм $^{3}$, гідрокарбонатної лужності більше ніж 2,0 ммоль/дм $\mathrm{Am}^{3}$, величини $\mathrm{pH}>6,8$, вмісту сірководню до 2,0 мг/дм³ . Крім того, за наявності у воді розчиненого карбон(IV) оксиду, постає необхідність у його вилученні із застосуванням компресорів або повітродувок.

У відомих реагентних схемах застосовується метод глибокої аерації з подальшим використанням таких реагентів, як хлор, озон, калій перманганат, розчинів вапна, коа-

(C) Квартенко О. М., 2019 
гулянтів, флокулянтів із наступним очищенням води на тонкошарових відстійниках, фільтрах з інертним завантаженням або сорбційних фільтрах. Використання вказаних реагентів призводить до збільшення вартості очищеної води, можливості утворення хлорорганічних сполук, продуктів озонолізу, а також необхідності використання додаткового технологічного обладнання, такого, як градирні, контактні резервуари, озонатори. Як альтернативний окисник для деструкції важкоокиснювальних органічних комплексів, перспективним $\epsilon$ використання високоактивних $\mathrm{OH}^{\bullet}$-радикалів, які утворюються у воді при використанні методу гідродинамічної кавітації (ГДК) [4]. За декілька останніх десятирічь у багатьох країнах світу велику вагу приділяють біологічному методу видалення з підземних вод розчинених сполук $\mathrm{Fe}(\mathrm{II})$ та $\mathrm{Mn}(\mathrm{II})$ [5; 6]. Але межі ефективного і раціонального використання цього методу для очищення багатокомпонентних підземних вод у поєднанні з фізико-хімічними методами, та можливість вилучення йонів важких металів $\left(\mathrm{Cr}^{6+}, \mathrm{Ni}^{2+}, \mathrm{Zn}^{2+}, \mathrm{Cu}^{2+}\right)$, фору, ПАР не було досліджено.

Видалення амонійних сполук нітрогену. У підземних водах вміст амонійного нітрогену супроводжується присутністю $\mathrm{H}_{2} \mathrm{~S} ; \mathrm{CO}_{2}$; $\mathrm{Mn}$; Fe. При pH 6-8 у воді головним чином знаходиться йон $\mathrm{NH}_{4}{ }^{+}$. Аналіз літературних даних [3; 7-9] дозволив зробити висновок щодо двох напрямів розвитку водоочисних методів: фізико-хімічних - хлорування, аерація в лужному середовищі, зворотний осмос, сорбція, іонний обмін на кліноптилітових фільтрах, електроліз; і біологічних - біологічна нітрифікація. При застосуванні методу хлорування (при рН 6,5-7,5; питома витрата хлору 6-15 мг/дм³) одночасно відбувається окиснення заліза та мангану, з подальшим видаленням зависі на освітлювальних фільтрах. У випадку значного вмісту органічних речовин, фенолів - утворюються хлорорганічні сполуки, що призводить до необхідності проведення дехлорування води, яка пройшла очищення. При озонуванні $\left(\mathrm{O}_{3} / \mathrm{NH}_{4}^{+}=14 / 1\right)$ в присутності йонів $\mathrm{Fe}(\mathrm{II})$ та $\mathrm{Mn}(\mathrm{II})$, а також розчинених органічних сполук, відбувається їх першочергове окиснення Оз. При використанні методу біофільтрації ( $\mathrm{pH}$ 7,5 - 8,5; витрата кисню 4,6 мгО $/$ мг) видаленні аміаку відбувається із добре аерованих вод на піщаних фільтрах. Використання технології видалення аміаку на цеолітах обмежено тим, що після вичерпання обмінної ємкості його необхідно регенерувати. Регенерація складна та енергоємна. До складу регенераційного блока входять: градирні для віддувки та нейтралізації аміаку, баки реагентів, насоси.

Методи видалення фенолів засновані на окисній здатності озону (в лужному середовищі 1,02 г $\mathrm{O}_{3}$ : на 1г $\mathrm{C}_{6} \mathrm{H}_{5} \mathrm{OH}$ ); гідроге́н перокси́ду (в кислому середовищі $\mathrm{pH} 4$ в присутності Fe(II) та при мольному співвідношенні 1:3); калій перманганату (мольне співідношення 1:9,3); хлору (утворює токсичні продукти в ході хімічної реакції деструкції фенолів); гідроксильні радикали (реакції деструкції можуть йти при значеннях рН вихідної води) $[3,7,10]$.

Виділення недосліджених частин загальної проблеми. Проведений аналіз сучасного стану технологій очищення багатокомпонентних слабокислих підземних вод із низьким лужним резервом свідчить про відсутність даних щодо їх комплексного очищення в межах однієї технологічної схеми від іонів важких металів, амонійного нітрогену, розчиненої органіки, комплексно-органічних сполук, фенолів, фтору, ПАР із використанням комбінаторики фізичних, біохімічних та фізико-хімічних методів.

Мета статті. Головною метою цієї роботи є розвиток науково-технічних засад у галузі комплексного очищення природних підземних вод з використанням комплексу фізичних, біохімічних та фізико-хімічних методів.

Виклад основного матеріалу. У результаті проведених теоретичних та експериментальних досліджень встановлено, що при відповідній комбінаториці як відомих так і удосконалених методів із використанням синергетичного ефекту швидкість проходження процесів комплексного очищення багатокомпонентних систем буде не на багато нижчою, ніж для однокомпонентних систем $\left(\mathrm{Fe}^{2+}\right)$. У слабокислих $(\mathrm{pH} 5,8-6,5)$ підземних водах із низь- 
TECHNICAL SCIENCES AND TECHNOLOGIES

ким лужним резервом (до 1,5 ммоль/дм³ ) в присутності сполук амонійного нітрогену (до 2,0 мг/дм $\left.{ }^{3}\right)$, фенолів (0,08-0,5 мг/дм³), комплексних сполук Fe(II) - ГК (до 10,0 мг/дм³), катіонів $\mathrm{Cr}^{6+}$ (до $0,5 \mathrm{m \Gamma} /$ дм$^{3}$ ), фтору (до $1,0 \mathrm{мг} /$ дм$^{3}$ ) рекомендовано застосовувати технологічну схему з використанням гідродинамічного кавітатору - контактної камери - підлуження води з наступною обробкою розчином коагулянту - фільтруванням.

На першому етапі відбувається процес деструкції та окиснення амонійного нітрогену та фенолів за наступними механізмами:

$$
\begin{aligned}
& \mathrm{NH}_{3}+\mathrm{H}_{2} \mathrm{O} \leftrightarrow \mathrm{NH}_{4} \mathrm{OH}, \\
& \mathrm{NH}_{4} \mathrm{OH} \leftrightarrow \mathrm{NH}_{4}^{+}+\mathrm{OH}^{-} .
\end{aligned}
$$

При проходженні такої води через гідродинамічний кавітаційний апарат відбуваються реакції, у результаті яких згідно з даними, наведеними в [4; 11-12], утворюються інтермедіати, які є досить сильними окисниками:

$$
\begin{aligned}
& \mathrm{OH}^{-}-1 \overline{\mathrm{e}} \rightarrow\left|\mathrm{OH}^{*}\right|, \\
& \mathrm{NH}_{4}^{+}+1 \overline{\mathrm{e}} \rightarrow \mathrm{NH}_{3}+\left|\mathrm{H}^{-}\right| .
\end{aligned}
$$

із подальшою їх рекомбінацією з утворенням молекулярних сполук [12; 13]:

$$
\begin{aligned}
& 2 \mathrm{OH}^{\bullet} \rightarrow \mathrm{H}_{2} \mathrm{O}_{2}, \\
& 2\left|\mathrm{H}^{\bullet}\right| \rightarrow \mathrm{H}_{2} \uparrow, \\
& \left|\mathrm{H}^{\bullet}\right|+\left|\mathrm{OH}^{\bullet}\right| \rightarrow \mathrm{H}_{2} \mathrm{O} .
\end{aligned}
$$

Як було зазначено вище, при схопуванні кавітаційних пухірців виникає високий тиск (1013,25 МПа $\approx 10000$ ат.) та температура (до 10000 К) [13]. За цих умов відбувається процес дисоціації гідроген пероксиду за радикальним механізмом:

$$
\begin{aligned}
& \mathrm{H}_{2} \mathrm{O}_{2} \leftrightarrow 2\left|\mathrm{OH}^{\bullet}\right|, \\
& \mathrm{H}_{2} \mathrm{O}_{2} \leftrightarrow \mathrm{H}_{2} \mathrm{O}+\left|\mathrm{O}^{\bullet}\right| .
\end{aligned}
$$

із подальшим окисненням $\mathrm{NH}_{3}$ та утворенням газоподібного $\mathrm{N}_{2}$ :

$$
2 \mathrm{NH}_{3}+3\left|\mathrm{O}^{\bullet}\right| \underset{1000 \mathrm{~K}}{\longrightarrow} \mathrm{N}_{2} \uparrow+3 \mathrm{H}_{2} \mathrm{O} .
$$

Одночасно у воді відбуваються реакції дисоціації фенолів:

$$
\mathrm{C}_{6} \mathrm{H}_{5} \mathrm{OH} \leftrightarrow \mathrm{C}_{6} \mathrm{H}_{5} \mathrm{O}^{-}+\mathrm{H}^{+} .
$$

При проходженні такої води через гідродинамічний кавітатор відбувається утворення радикалів $\mathrm{C}_{6} \mathrm{H}_{5} \mathrm{O}^{\bullet}$ та $\mathrm{H}^{\bullet}[10]$. Під дією локальних високих температур та тиску відбувається рекомбінація радикалів з утворенням ряду сполук:

$$
\begin{gathered}
2 \mathrm{C}_{6} \mathrm{H}_{5} \mathrm{O}^{\bullet}+2 \mathrm{H}^{\bullet} \rightarrow \mathrm{C}_{6} \mathrm{H}_{5}-\mathrm{O}-\mathrm{C}_{6} \mathrm{H}_{5}+\mathrm{H}_{2} \mathrm{O}, \\
2 \mathrm{H}^{\bullet} \rightarrow \mathrm{H}_{2} \uparrow, \\
2 \mathrm{C}_{6} \mathrm{H}_{5}^{\bullet} \rightarrow \mathrm{C}_{6} \mathrm{H}_{5}-\mathrm{C}_{6} \mathrm{H}_{5} .
\end{gathered}
$$

У контактній колоні проводиться початкове окиснення фенолів з їх розкладенням до проміжних складових [10]. Введення у воду розчину кальцинованої соди дозволяє призупиняти процес окиснення на стадії утворення інтермедіатів із наступною коагуляцією утворених сполук алюміній гідроксохлоридом.

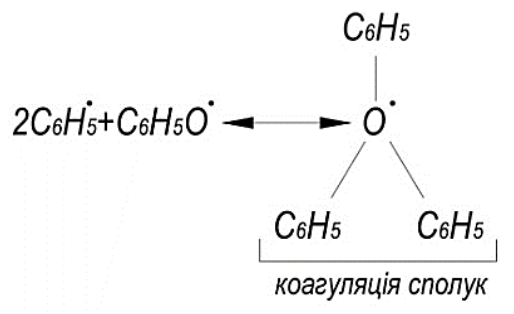


TECHNICAL SCIENCES AND TECHNOLOGIES

У присутності у воді залізогумінових комплексів відбувається їх руйнування та окиснення зв'язаного з ними $\mathrm{Fe}^{2+}$ :

$$
(\mathrm{RCOO})_{2} \mathrm{Fe}^{+2}+\left|\mathrm{O}^{\bullet}\right|+\mathrm{H}^{+}+\mathrm{RCOOH} \rightarrow(\mathrm{RCOO})_{3} \mathrm{Fe}^{3+}+\mathrm{H}_{2} \mathrm{O} .
$$

У результаті утворювалася колоїдна система, яка легко видалялася при застосуванні коагулянтів на фільтрах.

Введення додаткового джерела неорганічного вуглецю та підвищення величини гідрокарбонатної лужності впливає на інтенсифікацію процесу біологічного очищення води від сполук феруму та наступним утворенням матриксних структур, які у своїй структурі мають групи аніонів $\mathrm{PO}_{4}^{3-}, \mathrm{COO}^{-}, \mathrm{OH}^{-}[14]$ та $є$ природними сорбентами для катіонів $\mathrm{Cr}^{6+}, \mathrm{Al}^{3+}$ (рис. 1) [15]. Введення розчину кальцинованої соди дозволило підвищити ефективність видалення сполук феруму та розчинених органічних речовин відповідно до 94 та 44-50 \% (рис. 2).

$$
2 \mathrm{Na}^{+}+\mathrm{CO}_{3}^{2-}+\mathrm{Fe}^{2+}+2 \mathrm{HCO}_{3}^{-}+\mathrm{H}_{2} \mathrm{O} \rightarrow \mathrm{Fe}(\mathrm{OH})_{2}+3 \mathrm{CO}_{2} \uparrow+2 \mathrm{Na}^{+}+2 \mathrm{OH}^{-} \text {. }
$$
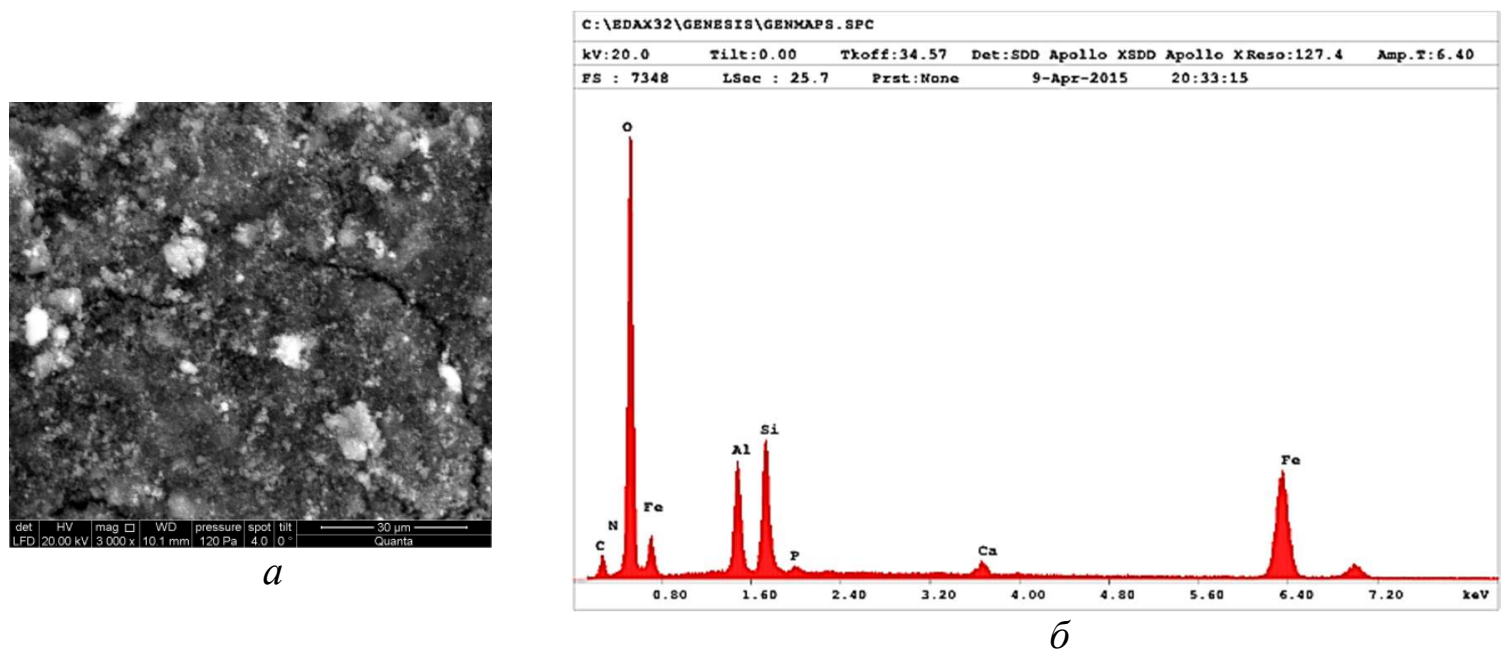

Рис. 1. Електронне зображення (а) та рентгеноспектральний аналіз (б) поверхні ділянки гранули фільтруючого завантаження

У результаті реакції у воду виділявся $\mathrm{CO}_{2}$, який використовувався мікроорганізмами роду Gallionella як додаткове джерело неорганічного вуглецю для побудови клітинної біомаси [16].

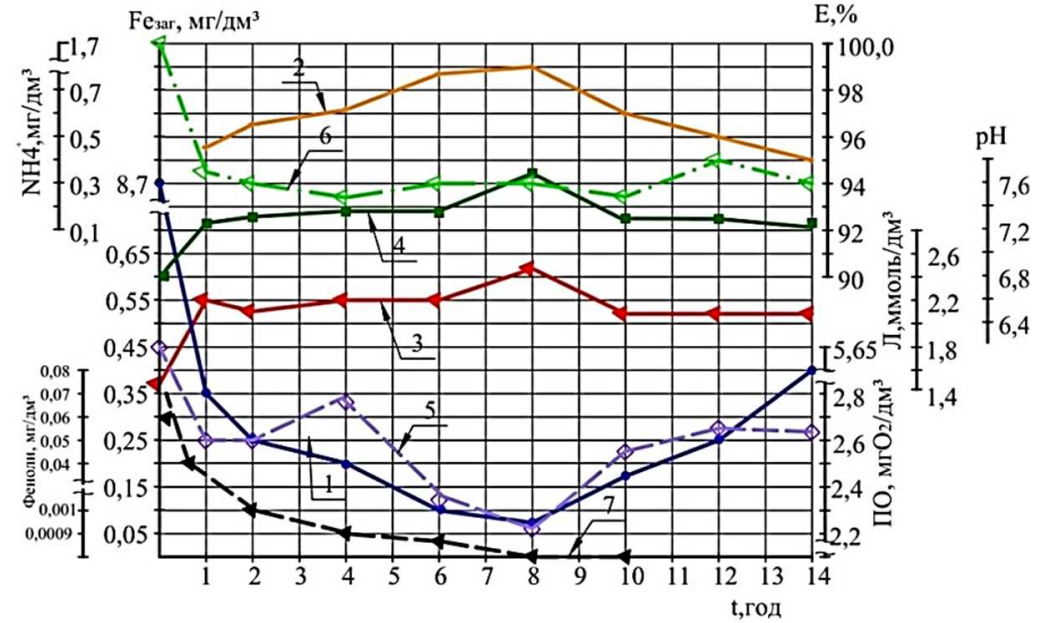

Рис. 2. Зміна концентрачї феруму (1), величин гідрокарбонатної лужності (3), рН (4), перманганатної окисності (5), амонійного нітрогену (6), фенолів (7); ефективності видалення феруму (2) протягом фільтроичклу (tк, год) 
TECHNICAL SCIENCES AND TECHNOLOGIES

Очищення води від катіонів $\mathrm{Cr}^{6+}$ засновано на хімічному відновленні біхромат та хромат-іонів катіонами $\mathrm{Fe}^{2+}$, які знаходяться у воді, а також $\mathrm{Fe}(\mathrm{OH})_{2}$, який утворюється у воді в результаті гідролізу $\mathrm{Fe}_{2} \mathrm{CO}_{3}$ у слабокислому або нейтральному середовищі:

$$
\begin{gathered}
\mathrm{Fe}\left(\mathrm{HCO}_{3}\right)_{2}+2 \mathrm{H}_{2} \mathrm{O}=\mathrm{Fe}(\mathrm{OH})_{2}+2 \mathrm{CO}_{2}+\mathrm{H}_{2} \mathrm{O} \\
6 \mathrm{Fe}(\mathrm{OH})_{2}+\mathrm{Cr}_{2} \mathrm{O}_{7}^{2-}+7 \mathrm{H}_{2} \mathrm{O} \rightarrow 6 \mathrm{Fe}(\mathrm{OH})_{3}+\mathrm{Cr}(\mathrm{OH})_{3}+2 \mathrm{OH}^{-} .
\end{gathered}
$$

На відновлення 1 г хрому(VI) необхідно 3,22 г ферум(II). Виведення продуктів реакції у вигляді $\mathrm{Cr}(\mathrm{OH})_{3}$ за межі зони реакції відбувається в результаті підлуження та коагулювання з наступними розділом фаз у товщі фільтруючого завантаження.

Крім того, у межах рН 5,0-6,5 на поверхні матриксних структур може видалятися фтор із розрахунку: 1 мг $\mathrm{F}$ на 1 мг $\gamma$-FeOOH.

Видалення амонійного нітрогену в контактному фільтруючому завантаженні можливо представити декількома механізмами залежно від параметрів якості води та якісного складу мікроорганізмів у підземних водах. У нейтральних та біля нейтральних підземних водах, у присутності хемолітоавтотрофних бактерій роду Gallionella, можливо розглядати процес сорбції йонів $\mathrm{NH}_{4}{ }^{+}$на поверхні матриксних структур bioмінералів, а також на клітинах самих бактерій, завдяки присутності на їхній поверхні функціональних груп: $\mathrm{PO}_{4}^{3-}, \mathrm{COO}^{-}, \mathrm{OH}^{-}$. Що найшло підтвердження в результатах проведеного нами рентгеноспектрального аналізу матриксних структур.

Блочно-модульна станція очищення підземних вод наведена на рис. 3. Результати досліджень очищення підземних вод на діючій станції (рис. 3) продуктивністю $5 \mathrm{~m}^{3} /$ год наведено на рис. 2. За результатами проведених теоретичних та експериментальних досліджень встановлено, що включення в технологічні схеми невеликих блоків (ГДК, підлуження) у відповідній послідовності з наявними технологічними спорудами (контактної колони - фільтрів) дозволило отримати швидкості окиснення не нижче ніж для однокомпонентних систем (рис. 2). За наявності у воді важко окиснюваних органічних сполук (амонійного нітрогену, фенолів, ферум-органічних комплексів) на першому ступені водоочищення слід застосовувати метод ГДК, який дозволяє руйнувати молекулярні зв'язки в складних органічних молекулах і частково їх окиснювати, переводячи із розчиненого до колоїдного стану.

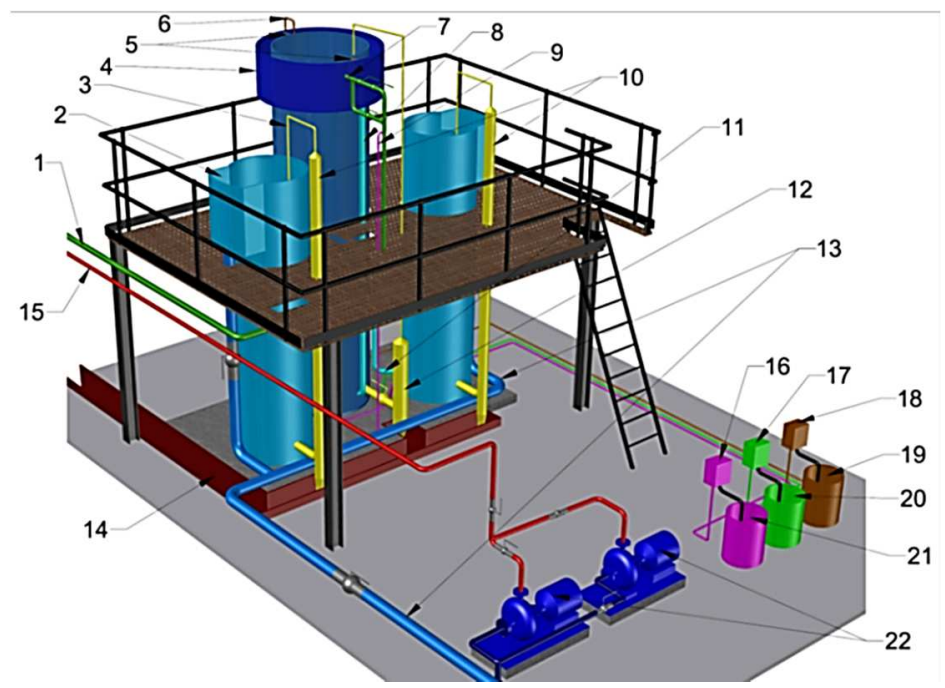

Рис. 3. Блочно-модульна станція очищення підземних вод:

1 - трубопровід подачі вихідної води; 2 - карман фільтру для збору та відведення фільтрату; 3 - трубка зриву вакууму; 4 - круговий перегородчастий змішувач; 5 - перегородки; 6 - патрубок подачі розчину коагулянту; 7 - кавітатор; 8 - відвід води до нижньої частини контактної колони; 9 - патрубок подачі розчину кальцинованої соди; 10, 12 - гідророботи; 11 - патрубок подачі води на фільтри; 13 - трубопровід відведення фільтрату; 14 - канал збору та відведення відпрацьованих промивних вод; 15 - трубопровід подачі води споживачам; 16, 17, 18 - насоси дозатори;

19, 20, 21 - баки розчинів коагулянту, флокулянту, кальцинованої соди 
Підлуження води розчином кальцинованої соди дозою $35-45$ мг/дм ${ }^{3}$ із наступною обробкою розчинами коагулянту дозою 15-20 мг/дм ${ }^{3}$ та неіоногеного флокулянту дозою 8-10 мг/дм ${ }^{3}$ дозволяло дестабілізувати створену колоїдну систему 3 наступним розподілом фаз в контактному завантаженні. На наступному етапі відбувався процес доокиснення та адсорбції зазначених речовин на матриксних структурах розташованих у міжпоровому просторі.

Середні концентрації катіонів $\mathrm{Fe}^{2+}$ та $\mathrm{NH}_{4}{ }^{+}$у межах фільтроцикла становили відповідно 0,2-0,3 мг/дм ${ }^{3}$ та 0,25-0,4 мг/дм³ , що відповідало 96-99 та 76-85 \% ефектам очищення відповідно. Величина перманганатної окисності зменшилася до 2,3-2,65 мгО $\mathrm{O}_{2} /$ дм$^{3}$. Наявності сірководню та фенолів у фільтраті не було визначено. Встановлено оптимальні швидкості фільтрування 3-5 м/год. Оптимальна тривалість фильтроциклу при зазначених концентраціях забруднюючих речовин складала в середньому 12 годин.

Висновки відповідно до статті. Для очищення слабокислих $(\mathrm{pH}$ до 6,5) підземних вод 3 низьким лужним резервом (до 1,5 ммоль/дм ${ }^{3}$ ) які містять ферум гумінові комплекси

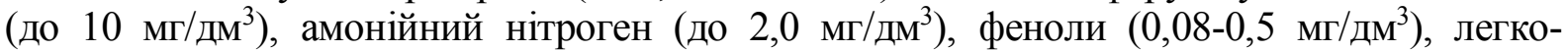
окиснювальні органічні сполуки (до 8,0 мг $\mathrm{O}_{2} /$ дм$^{3}$ ), катіони $\mathrm{Cr}^{6+}$ (до $0,5 \mathrm{Mг} /$ дм$^{3}$ ) розроблена та впроваджена технологія в основі якої закладено принцип синергізму комплексного використання фізичних, фізико-хімічних та біохімічних методів. Використання на першій стадії методу гідродинамічної кавітації дозволяє: 1 - проводити окиснення $\mathrm{NH}_{3} 3$ утворенням газоподібного $\mathrm{N}_{2} ; 2$ - руйнувати молекулярні зв'язки в складних органічних молекулах і частково їх окиснювати, переводячи із розчиненого до колоїдного стану; 3 утворення активних молекул із групами $\mathrm{COO}^{-}$, які в подальшому легко вступають в реакцію з продуктами гідролізу оксихлориду алюмінію; 4 - підлуження води розчином кальцинованої соди дозволяє зупиняти окиснення фенолів на стадії утворення інтермедіатів 3 наступним їх виведенням за межі зони реакції в процесі коагулювання; 5 - одночасно із цим введення розчину кальцинованої соди дозволяє корегувати величини рН та гідрокарбонатної лужності води, а також вводити додаткове джерело неорганічного вуглецю для активації життєдіяльності феробактерій, що призводить до прискорення процесів біохімічного окиснення сполук феруму та утворення матриксних структур феробактерій; 6 - в свою чергу матриксні структури дозволяють проводити процеси адсорбції на їх поверхні катіонів $\mathrm{NH}_{4}{ }^{+}, \mathrm{Cr}^{6+}$, а також катіонів $\mathrm{Al}^{3+}$, які утворилися при гідролізі алюміній гідроксохлориду та не вступили у взаємодію із колоїдними частинками; 7 - хімічному відновленні біхромат та хромат-іонів катіонами $\mathrm{Fe}^{2+}$ з подальшим видаленням $\mathrm{Cr}(\mathrm{OH})_{3}$ за межі зони реакції в результаті підлуження та коагулювання.

\section{Список використаних джерел}

1. Квартенко О. М. Системний підхід до обгрунтування нових та удосконалення існуючих технологій кондиціонування багатокомпонентних підземних вод. Комунальне господарство міст. Серія: Технічні науки та архітектура. 2018. Вип. 140. С. 98-103.

2. Орлов В. О. Знезалізнення підземних вод спрощеною аерацією та фільтруванням: монографія. Рівне: Видавничий центр НУВГП, 2008. 158 с.

3. Технические записки по проблемам воды: пер. с англ.: в 2-т. Т. 1 / под ред. Т. А. Карюхиной, И. Н. Чурбановой. Москва: Стройиздат, 1983. 607 с.

4. Вітенько Т. Н. Механізм та кінетичні закономірності інтенсифікуючої дії гідродинамічної кавітації у хіміко-технологічних процесах: дис. ... д-ра техн. наук: 05.17.08 / Терноп. нац. техн. ун-т ім. І. Пулюя. Тернопіль, 2010. 436 с.

5. Mouchet P. From Conventional to Biological Removal of Iron and Manganese in France. Journal of the American Water Works Association. 1992. Vol. 84, no 4. P. 158-167.

6. Askerniia A. A., Sorokina A. Iu., Dubinina G. A. Microbiological aspects of natural underground water deironing and demanganation. Vodosnabzhenie i Sanitarnaia Tekhnika. 2014. No. 12. P. 14-21.

7. Журба М. Г., Говорова Ж. М. Водоснабжение. Улучшение качества воды: учебник для вузов. Том 2. Москва: Издательство АСВ, 2008. 544 с. 
TECHNICAL SCIENCES AND TECHNOLOGIES

8. Шиян Л. Н., Юрмазова Т. А., Галанов А. И., Лобанова Г. Л. Электрохимические методы очистки подземных вод с высокой концентрацией железа. Современные проблемы науки и образования. 2012. № 6. C. 12.

9. Lytle D. A., Williams D., Muhlen Ch., Pham M., Kelty K. Biological Treatment Process for the Removal of Ammonia from a Small Drinking Water System in Iowa: Pilot to Full-Scale. Water Supply and Water Resources Division. 2014. P. 1-53.

10. Квартенко О. М., Саблій Л. А., Грюк І. Б. Вилучення фенолів із багатокомпонентних підземних вод методом гідродинамічної кавітації. Вісник Хмельницького національного університету. Серія: Технічні науки. 2017. № 5 (253). С. 83-88.

11. Витенько Т. Н., Гумницкий Я. М. Механизм активирующего действия гидродинамической кавитации на воду. Химия и технология водыл. 2007. № 5. С. 231-237.

12. Витенько Т. Н., Гумницкий Я. М. Механізм реакцій гідроксильних радикалів при обробці водиу кавітаційному полі. Eastern-European Journal of Enterprise Technologies. 2010. № 6/6 (48). Р. 60-63.

13. Маргулис М. А. Основы звукохимии. Москва: Химия, 1984. 272 с.

14. Букреева В. Ю., Грабович М. Ю., Епринцев А. Т., Дубинина Г. А. Сорбция коллоидных соединений оксидов железа и марганца с помощью железобактерий на песчаных загрузках очистных сооружений водоподъемных станций. Сорбциионные и хроматографические проиессы. 2009. Т. 9. Вып. 4. С. 506-514.

15. Kvartenko A., Orlov V., Pletuk O. Research into the biosorption process of heavy metal ions by the sediments from stations of biological iron removal. Eastern-European Journal of Enterprise Technologies. 2017. № 4/10 (88 ). P. 37-43. DOI: 10.15587/1729-4061.2017.107201.

16. Emerson D., Field E., Olga Chertkov O., Davenport K. W., Goodwin L., Munk C., Nolan M., Woyke T. Comparative genomics of freshwater Fe-oxidizing bacteria: implications for physiology, ecology, and systematics. Frontiers in Microbiology. Evolutionary and Genomic Microbiology. 2013. Volume 4. Article 254.

\section{References}

1. Kvartenko O. M. (2018). Systemnyi pidkhid do obgruntuvannia novykh ta udoskonalennia isnuiuchykh tekhnolohii kondytsionuvannia bahatokomponentnykh pidzemnykh vod [A systematic approach to justifying new and improving existing conditioning technologies for multi-component groundwater]. Komunalne hospodarstvo mist. Seriia: Tekhnichni nauky ta arkhitektura - Utilities of cities. Series: Engineering and Architecture, 140, 98-103 [in Ukrainian].

2. Orlov, V. O. (2008). Znezaliznennia pidzemnykh vod sproshchenoiu aeratsiieiu ta filtruvanniam. [Groundwater removal with simplified aeration and filtration]. Rivne: NUBGP Publishing Center [in Ukrainian].

3. Barack, K., Beben, J., Bernard, J. (1983). Tehnicheskie zapiski po problemam vody [Public health]. Moskva: Stroiizdat [in Russian].

4. Vitenko, T. N. (2010). Mekhanizm ta kinetychni zakonomirnosti intensyfikuiuchoi dii hidrodynamichnoi kavitatsii u khimiko-tekhnolohichnykh protsesakh [Mechanism and kinetic laws of intensity of dynamics of hydrodynamic cavitacy in chemical and technological processes] (Doctor's thesis). Ternop. nat. tech. University. I. Pulyuya, Ternopil [in Ukrainian].

5. Mouchet, P. (1992). From Conventional to Biological Removal of Iron and Manganese in France. Journal of the American Water Works Association, 84, 4, 158-167.

6. Askerniia, A. A., Sorokina, A. Iu., Dubinina, G. A. (2014). Microbiological aspects of natural underground water deironing and demanganation. Vodosnabzhenie i Sanitarnaia Tekhnika, 12, 14-21.

7. Zhurba, M. G. (Ed.). (2008). Vodosnabzhenie. Uluchshenie kachestva vody [Water supply. Improving Water Quality] (vol. 2). Moscow: Publishing house ACB [in Russian].

8. Shiyan, L. N., Yurmazova, T. A., Galanov, A. I., Lobanova, G. L. (2012). Elektrohimicheskie metody ochistki podzemnyh vod s vysokoj koncentraciej zheleza [Electrochemical methods of groundwater treatment with a high concentration of iron]. Sovremennye problemy nauki i obrazovaniiaModern problems of science and education, 6, 12 [in Russian].

9. Lytle, D. A., Williams, D., Muhlen, Ch., Pham, M., Kelty, K. (2014). Biological Treatment Process for the Removal of Ammonia from a Small Drinking Water System in Iowa: Pilot to FullScale. Water Supply and Water Resources Division, 1-53. 
TECHNICAL SCIENCES AND TECHNOLOGIES

10. Kvartenko, O. M., Sablii, L. A., Hriuk, I. B. (2017). Vyluchennia fenoliv iz bahatokomponentnykh pidzemnykh vod metodom hidrodynamichnoi kavitatsii [Extraction of phenols from multicomponent groundwater by hydrodynamic cavitation]. Bulletin of Khmelnitsky National University. Series: Technical Sciences. Khmelnytskyi: Khmelnytsky National University, 5 (253), 83-88 [in Ukrainian].

11. Vitenko, T. N., Gumnitskyi, Ia. M. (2007). Mehanizm aktiviruyushego dejstviya gidrodinamicheskoj kavitacii na vodu [The mechanism of the activating effect of hydrodynamic cavitation on water]. Khymiia i tekhnologiia vody-Chemistry and water technology, 5, 231-237 [in Russian].

12. Vytenko, T. N., Humnytskyi, Ya. M. (2010). Mekhanizm reaktsii hidroksylnykh radykaliv pry obrobtsi vody u kavitatsiinomu poli [Mechanism of reactions of hydroxyl radicals in water treatment in a cavitation field]. Eastern-European Journal of Enterprise Technologies, 6/6 (48), 60-63 [in Ukrainian].

13. Margulis, M. A. (1984). Osnovy zvukokhimi - Osnovy zvukohimii. Moscow: Khimiia [in Russian].

14. Bukreeva, V. Yu., Grabovich, M. Yu., Eprincev, A. T., Dubinina, G. A. (2009). Sorbtsiia kolloidnykh soedinenii oksidov zheleza i margantsa s pomoshiu zhelezobakterii na peschanykh zagruzkakh otshistnykh sooruzhenii vodopodemnykh stantsii [Sorption of colloidal compounds of iron and manganese oxides using iron bacteria on sandy loads of treatment facilities of water-lifting stations]. Sorbtsionnye i khromatograficheskie protsessy - Sorption and chromatographic processes, 9 (4), 506-514 [in Russian].

15. Kvartenko, A., Orlov, V., Pletuk, O. (2017). Research into the biosorption process of heavy metal ions by the sediments from stations of biological iron removal. Eastern-European Journal of Enterprise Technologies, 4/10 (88), 37-43. DOI: 10.15587/1729-4061.2017.107201.

16. Emerson, D., Field, E., Chertkov, O., Davenport, K. W., Goodwin, L., Munk, C., Nolan, M., Woyke, T. (2013). Comparative genomics of freshwater Fe-oxidizing bacteria: implications for physiology, ecology, and systematics. Frontiers in Microbiology. Evolutionary and Genomic Microbiology, 4, 254.

$U D C 628.16$

\section{Alexander Kvartenko}

\section{USE OF COMBINED METHODS IN TECHNOLOGICAL TREATMENT OF MULTI-COMPONENT UNDERGROUND WATERS}

Urgency of the research. Existing technologies are extensive ones and they do not envisage the comprehensive treatment of underground waters from pollutions of natural and androgenic origin.

Target setting. Scientific substantiation, research and introduction into practice of the technological solution which envisages the comprehensive treatment as a result of combining known and improved methods.

Actual scientific researches and issues analysis. The most widespread is the technology of treatment by the method of simplified aeration-filtration which is of limited application through a series of indices $\left(\mathrm{Fe}^{2+}<10 \mathrm{mg} / \mathrm{dm}^{3}, \mathrm{pH}>6,8\right.$, hydrocarbonate alkalinity $>2,0$ mmole/ $\mathrm{dm}^{3}, \mathrm{H}_{2} \mathrm{~S}<2,0$ mmole/dm ${ }^{3}$ ).

Uninvesigated parts of general defining. The development and introduction into practice of the technology based on the principle of the synergy of the comprehensive use of combined methods.

The research objective. The development of scientific-technical principles in the branch of the comprehensive treatment of natural underground waters using combined methods.

The statement of basic materials. It is established that under the combination of known and improved methods in using the synergic effect the undergoing processes of the treatment of multi-component systems is not by far less than for onecomponent ones $\left(\mathrm{Fe}^{2+}\right)$. The theoretical principles have been developed. of the comprehensive treatment of underground waters from compounds of ferrum, ammonia nitrogen, phenols, chromium (IV), fluorine using methods of hydrodynamic cavitation - alkalization - coagulation - biochemical treatment - filtration.

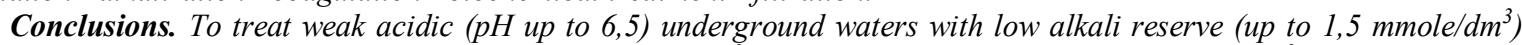
which contain ferrum-humin complexes (up to $10 \mathrm{mg} / \mathrm{dm}^{3}$ ), ammonia nitrogen (up to $2,0 \mathrm{mg} / \mathrm{dm}^{3}$ ), phenols $(0,08$ $0,5 \mathrm{mg} / \mathrm{dm}^{3}$ ), easily oxidized organic compounds (up to $8 \mathrm{mg} \mathrm{O}_{2} / \mathrm{dm}^{3}$ ), cations $\mathrm{Cr}^{6+}$ (up to $0,5 \mathrm{mg} / \mathrm{dm}^{3}$ ) the technology has been developed and put into practice based on the principle; of the synergic use of known and improved combined methods.

Keywords: comprehensive treatment; matrix structures; hydrodynamic cavitation; phenols; ammonia nitrogen.

Fig.: 3. References: 16.

Квартенко Олександр Миколайович - кандидат технічних наук, доцент, доцент/докторант, Національний університет водного господарства та природокористування (вул. Соборна, 11, м. Рівне, 33028, Україна).

Kvartenko Alexander - PhD in Technical Sciences, Assistant Professor, Assistant Professor/doctoral, National University of Water and Environmental Engineering (11 Soborna Str., 33028 Rivne, Ukraine).

E-mail: as-755@rambler.ru

Квартенко О. Застосування комбінованих методів у технологіях очищення багатокомпонентних підземних вод. Технічні науки та технології. 2019. № 4 (18). С. 215-222. 